\title{
Correlation of Progranulin, Granulin, Adiponectin and Vaspin with Metaflammation (hs-CRP) in Indonesian Obese Men
}

\author{
Rosalia E. Napitupulu ${ }^{1,2,}$, Anna Meiliana ${ }^{1,3}$, Andi Wijaya ${ }^{1,3}$ \\ ${ }^{1}$ Postgraduate Program in Clinical Biochemistry, Hasanuddin University, Jl. Perintis Kemerdekaan Km.10, Makassar, Indonesia \\ ${ }^{2}$ Prodia the CRO, Prodia Tower $6^{\text {th }}$ Floor, Jl. Kramat Raya No.150, Jakarta, Indonesia \\ ${ }^{3}$ Prodia Clinical Laboratory, Jl. Cisangkuy No.2, Bandung, Indonesia \\ *Corresponding author. E-mail: rosalia.napitupulu@gmail.com
}

\section{Abstract}

B ACKGROUND: Obesity is closely related to chronic, low grade systemic inflammation (metaflammation) and it leads to further metabolic complications such as hypertension, atherosclerosis, and type 2 diabetes due to the adipocytokine imbalance. This study was carried out to assess the correlation between progranulin, granulin, adiponectin and visceral adipose tissue-derived serine protease inhibitor (Vaspin) with metaflammation (high sensitivity C-reactive protein (hsCRP)) in centrally obese men.

METHODS: This study was observational with a cross sectional design involving 60 men aged 30-60 years, consisted of 43 obese men (waist circumference (WC) $\geq 90 \mathrm{~cm}$ ) and 13 non obese men (WC $<90 \mathrm{~cm}$ ), with no hypertension, and no renal dysfunction. Anthropometric parameters, creatinine, serum glutamic oxaloacetic transferase (SGOT), serum glutamic piruvic transferase (SGPT) and hs-CRP levels were measured. Serum concentrations of progranulin, granulin, adiponectin and Vaspin were measured by ELISA.

RESULTS: This study showed in obese men a significant correlation between hs-CRP and Vaspin ( $\mathrm{r}=0.305 ; p=0.046)$, non-significant correlation between hs-CRP and progranulin $(\mathrm{r}=0.048 ; p=0.758)$, between hs-CRP and granulin $(\mathrm{r}=$ $-0.223 ; p=0.150$ ), also between hs-CRP and adiponectin ( $\mathrm{r}=-$ $0.121 ; p=0.439$ ). Similar patterns were observed between adipokines level and WC. There were 3 patterns showing increase or decrease of adipokines value with $\mathrm{WC}$ between 80-86 cm; subsequently the pattern tended to become flat with WC between $86-105 \mathrm{~cm}$, then showing increase or decrease of adipokines value with $\mathrm{WC}>105 \mathrm{~cm}$.

\section{Abstrak}

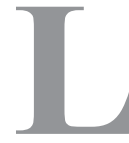

ATAR BELAKANG: Obesitas berhubungan dekat dengan inflamasi sistemik tingkat rendah yang kronik (metaflamasi), dan menyebabkan komplikasi penyakit metabolik lanjutan, antara lain hipertensi, aterosklerosis, dan diabetes tipe 2 terkait dengan ketidakseimbangan adipositokin. Penelitian ini bertujuan untuk menilai hubungan antara progranulin, granulin, adiponektin dan visceral adipose tissue-derived serine protease inhibitor (Vaspin) dengan metaflamasi (high sensitivity $C$-reactive protein (hs-CRP)) pada pria obesitas sentral.

METODE: Penelitian ini menggunakan desain potong lintang melibatkan 60 pria usia 30-60 tahun, yang terdiri atas 43 pria obes (lingkar pinggang $(\mathrm{LP}) \geq 90 \mathrm{~cm}$ ) dan 13 pria non obes $(\mathrm{LP}<90 \mathrm{~cm})$, tidak menderita hipertensi, non disfungsi ginjal. Dilakukan pemeriksaan antropometri, nilai kreatinin, serum glutamic oxaloacetic transferase (SGOT), serum glutamic piruvic transferase (SGPT) dan hs-CRP. Konsentrasi progranulin, granulin, adiponektin dan Vaspin diukur menggunakan metode ELISA.

HASIL: Hasil penelitian ini menunjukkan pada pria obesitas terdapat korelasi signifikan antara hs-CRP dan Vaspin $(\mathrm{r}=0,305 ; p=0,046)$, korelasi tidak bermakna antara hs-CRP dan progranulin ( $\mathrm{r}=0,048 ; p=0,758)$, antara hs-CRP dan granulin $(\mathrm{r}=-0,223 ; p=0,150)$, serta antara hs-CRP dan adiponektin $(\mathrm{r}=-0,121 ; p=0,439)$. Terdapat kesamaan pola antara kadar adipokin dan LP. Terdapat 3 jenis pola, dimana menunjukkan peningkatan atau penurunan kadar adipokin pada LP antara 80-86 cm; kadar adipokin yang stabil pada LP 86-105 cm, kemudian menunjukkan peningkatan atau penurunan kadar adipokin pada LP antara $>105 \mathrm{~cm}$. 
CONCLUSION: We found metaflammation (hs-CRP) was significantly correlated with Vaspin, but not with progranulin, granulin and adiponectin, in obese men. We suggest the possibility of a dynamic expression of adipokines related to $\mathrm{WC}$ that are subjected to adipocytes hypertrophy-hyperplasia phenomenon.

KEYWORDS: progranulin, granulin, adiponectin, Vaspin, hs-CRP, metaflammation, central obesity

Indones Biomed J. 2013; 5(2): 107-14
KESIMPULAN: Kami menemukan bahwa metaflamasi (hs-CRP) berkorelasi signifikan dengan Vaspin, tetapi tidak berkorelasi signifikan dengan granulin, progranulin dan adiponektin, pada pria obes. Kami menduga adanya ekspresi dinamis adipokin yang berkaitan dengan LP merupakan fenomena hipertrofi-hiperplasia adiposit.

KATA KUNCI: progranulin, granulin, Vaspin, hs-CRP, metaflamasi, obesitas sentral.

\section{Introduction}

Obesity is known to be associated with chronic low-grade inflammation. Obesity-related inflammation can initiate complications such as hypertension, atherosclerosis, dyslipidemia, insulin resistance and type 2-diabetes, which are characterized as metabolic syndrome (MS). Recent studies have shown that adipose tissue serves not only as an energy storage organ, but also as an endocrine organ that produces adipocytokine or adipokine.(1)

Obesity causes adipokine imbalance that may lead to decreased expression of adiponectin. Adiponectin plays an important role in the mechanism of action of insulin. Several clinical and experimental studies have reported that adiponectin has functions as anti-inflammatory and antidiabetes, increases insulin sensitivity and protects against obesity-related cardiovascular disorders. Low adiponectin level can occur in insulin resistance and diabetes.(2)

Progranulin is a growth factor that is widely expressed and implied for proliferation, wound repair, embryonic development, signal transduction, tumor genesis and inflammation. Progranulin acts as a chemo-attractant molecule similar to monocyte chemoattractant protein-1 (MCP-1), which may contribute to increased infiltration of macrophages in omental adipose tissue in visceral obesity. Progranulin is an important molecule in inflammatory responses. Chronic inflammation is often associated with central obesity; however, the role of progranulin in central obesity, type 2-diabetes, and dyslipidemia is unclear. Previous study by Youn, et al. found a close relationship between C-reactive protein (CRP) and serum progranulin and showed that progranulin is a novel biomarker for chronic inflammatory response in central obesity and other related disorders. $(3,4)$

Progranulin is known as the precursor of granulin.
The physiological and pathophysiological functions of progranulin are quite complex. Proganulin can show antiinflammatory and pro-inflammatory actions. A previous study suggests that the full-length form of the protein shows the anti-inflammatory effects while the proteolytic cleaveages shows the pro-inflammatory effects.(5)

Vaspin (visceral adipose tissue-derived serine protease inhibitor) is a serine protease inhibitor family member. The mechanism of anti-protease activity of Vaspin still remains unclear. Hida et al., have suggested Vaspin administration to mice can suppress gene expression of leptin, resistin, and Tumor Necrosis Factor (TNF)- $\alpha$, and increases peripheral tissue resistance to insulin and increases the expression of glucose transporter-4 and adiponectin, which affect resistance to insulin. Vaspin expressed in obese subjects and cannot be detected in lean subjects with normal glucose tolerance. Vaspin secreted in adipose tissue is regulated and may indicate a compensatory response associated obesity, insulin resistance and type 2-diabetes. Vaspin levels increase in rats suffering from obesity and insulin resistance.(6-8)

Chronic low-grade systemic inflammation is associated with metabolic disorder, known as metaflammation. High sensitivity CRP (hs-CRP) is an acute phase protein used as a marker for metaflammation. Several previous studies have shown elevated levels of hs-CRP were significantly associated with metabolic abnormalities.(9)

This study was carried out to investigate the correlation of progranulin, granulin, adiponectin and Vaspin with metaflammation (hs-CRP) in obese men.

\section{Methods}

\section{Subjects}

The study subjects were recruited from the community in Jakarta, consisted of 43 central obese men (waist 
circumference $(\mathrm{WC}) \geq 90 \mathrm{~cm}$ ) and 17 non central obese men $(\mathrm{WC}<90 \mathrm{~cm}$ ). All subjects aged 30 to 60 years, had no history of hypertension or renal dysfunction. WC was determined by measuring the waist between the lower rib and iliac crest. Information on medical history, current condition, and drug consumption was obtained by interview. Other characteristics such as smoking and alcohol habits were obtained by using a structured questionnaire. Subjects with systolic pressure of $\geq 140 \mathrm{mmHg}$ and a diastolic pressure of $\geq 90 \mathrm{mmHg}$ or glomerular filtration rate (GFR) $<60 \mathrm{~mL} /$ minute or serum glutamic oxaloacetic transferase (SGOT) / serum glutamic piruvic transferase (SGPT) above 2 times the normal value or hs-CRP $\geq 10 \mathrm{mg} / \mathrm{L}$ were excluded from the study. This study was approved by the Ethics Committee of the Medical Faculty, Hasanuddin University, Makassar (registered number: UH13030098), and a written informed consent was obtained from each subject.

\section{Blood collection and biochemical analyses}

Blood samples were collected in the morning after overnight fasting for 12 hours, and serum was separated not more than
2 hours after blood collection. Serum levels of SGOT, SGPT, creatinine, and hs-CRP were assayed using auto analyzer Cobas (Roche Diagnostics, Rotkreuz, Switzerland). Commercially available enzyme-linked immunosorbent assay kits were used to measure circulating adiponectin (Sekisui Chemical Co., Ltd, Tokyo, Japan), progranulin (R\&D Systems, Inc., Minneapolis, MN), granulin (Cusabio Biotech Co, Ltd., Wuhan, China) and Vaspin (BiovendorLaboratorni medicina a.s., Karasek, Czech) levels.

\section{Statistical analysis}

Statistical analysis was performed using IBM SPSS for Windows version 19.0 (IBM Corp., Armonk, NY). All values are expressed as mean \pm standard deviation (SD), unless otherwise specified. Subjects were divided into 2 groups based on WC category. Pearson correlation coefficients were calculated to evaluate the relationships between serum progranulin, granulin, adiponectin and hs-CRP, while Spearman correlation coefficients were calculated to evaluate the relationships between serum Vaspin and hs-CRP. Hypothesis testing was two-tailed at a significance level of 0.05 .

Table 1. Clinical and biochemical characteristics of the study subjects.

\begin{tabular}{|c|c|c|c|c|c|c|c|c|c|c|c|c|}
\hline \multirow{2}{*}{ Parameter } & \multicolumn{4}{|c|}{ Overall } & \multicolumn{4}{|c|}{ Obese } & \multicolumn{4}{|c|}{ Non Obese } \\
\hline & Mean & SD & Min & Max & Mean & SD & Min & Max & Mean & SD & Min & $\operatorname{Max}$ \\
\hline Age (years) & 43.41 & 7.93 & 30.70 & 59.60 & 42.76 & 7.51 & 30.70 & 56.60 & 45.06 & 8.95 & 31.00 & 59.60 \\
\hline WC (cm) & 93.40 & 9.02 & 68.00 & 116.00 & 97.60 & 6.09 & 90.00 & 116.00 & 82.76 & 5.93 & 68.00 & 89.00 \\
\hline BMI $\left(\mathrm{kg} / \mathrm{m}^{2}\right)$ & 26.50 & 3.51 & 17.17 & 34.37 & 28.06 & 2.59 & 23.59 & 34.37 & 22.54 & 2.18 & 17.17 & 26.12 \\
\hline Height (cm) & 166.73 & 4.76 & 152.00 & 177.00 & 166.91 & 4.69 & 152.00 & 175.00 & 166.29 & 5.04 & 161.00 & 177.00 \\
\hline Weight (cm) & 73.76 & 10.81 & 44.50 & 98.00 & 78.20 & 8.12 & 65.00 & 98.00 & 62.53 & 8.43 & 44.50 & 80.00 \\
\hline SBP (mmHg) & 111.97 & 10.42 & 90.00 & 130.00 & 111.70 & 10.68 & 90.00 & 130.00 & 112.65 & 10.02 & 90.00 & 130.00 \\
\hline DBP (mmHg) & 75.25 & 6.91 & 60.00 & 85.00 & 75.23 & 7.23 & 60.00 & 85.00 & 75.29 & 6.24 & 60.00 & 80.00 \\
\hline SGPT (mg/dL) & 26.17 & 13.64 & 6.00 & 62.00 & 29.23 & 13.99 & 10.00 & 62.00 & 18.41 & 9.10 & 6.00 & 43.00 \\
\hline SGOT (mg/dL) & 20.88 & 6.34 & 12.00 & 47.00 & 21.58 & 6.87 & 12.00 & 47.00 & 19.12 & 4.43 & 13.00 & 28.00 \\
\hline Creatinine (mg/dL) & 0.87 & 0.12 & 0.59 & 1.16 & 0.89 & 0.13 & 0.59 & 1.16 & 0.83 & 0.10 & 0.66 & 1.13 \\
\hline GFR & 103.88 & 11.88 & 76.00 & 135.00 & 103.05 & 12.73 & 76.00 & 135.00 & 106.00 & 9.41 & 81.00 & 117.00 \\
\hline hs-CRP (mg/L) & 2.23 & 1.56 & 0.30 & 6.50 & 2.55 & 1.65 & 0.30 & 6.50 & 1.43 & 0.92 & 0.50 & 4.10 \\
\hline Adiponectin (ng/mL) & 4.27 & 1.89 & 1.59 & 9.12 & 4.13 & 1.74 & 1.87 & 8.42 & 4.65 & 2.22 & 1.59 & 9.12 \\
\hline Progranulin (ng/mL) & 62.49 & 10.93 & 46.15 & 88.38 & 62.88 & 11.31 & 46.15 & 88.38 & 61.53 & 10.18 & 46.33 & 78.49 \\
\hline Granulin $(\mathrm{ng} / \mathrm{mL})$ & 166.04 & 64.31 & 70.12 & 338.10 & 163.92 & 62.65 & 70.12 & 329.17 & 171.40 & 70.01 & 79.22 & 338.10 \\
\hline Vaspin (ng/mL) & 0.83 & 2.16 & 0.00 & 8.13 & 0.72 & 2.07 & 0.00 & 8.13 & 1.10 & 2.42 & 0.00 & 6.28 \\
\hline
\end{tabular}

Kolmogorov-Smirnov test was used to test sample distributions. BMI: body mass index, SBP: systolic blood pressure, DBP: diastolic blood pressure. 


\section{Results}

\section{Clinical characteristics of subjects}

Table 1 shows the anthropometric and metabolic characteristics of the subjects: 47 obese men aged 42.8 \pm 7.5 (range: 30.7-56.6) years, with the mean WC of $97.6 \pm 6.1$ (range: $90-116$ ) $\mathrm{cm}$ and 17 non obese men aged $45.1 \pm 8.9$ (range: $31-59.6$ ) years, with the mean WC of $82.8 \pm 5.9$ (range: $68-89$ ) $\mathrm{cm}$. The scatter graph shows that the patterns of progranulin, adiponectin, and granulin were similar, whereas Vaspin and hs-CRP showed a similar pattern as well. At WC between $80-85 \mathrm{~cm}$, progranulin, granulin and adiponectin levels tended to decline while WC was increasing. At WC $85-105 \mathrm{~cm}$, the levels tended to be stable, even slightly increased. At WC above $105 \mathrm{~cm}$, the levels of these three parameters continued to decline. On the other hand, hs-CRP showed declining levels with WC up to $80 \mathrm{~cm}$, and with WC above $80 \mathrm{~cm}$ they tended to increase, whereas vaspin began to increase at WC $95 \mathrm{~cm}$ (Figure 1).

\section{Association of Progranulin, Granulin, Adiponectin and Vaspin with Inflammation (hs-CRP)}

Table 2 and Figure 2 show the trend line of correlation between adipokines vs. hs-CRP. Spearman correlation showed a significant correlation in obese men between

Table 2. Correlation between IMT, WC, hs-CRP, Progranulin, Granulin, Adiponectin and Vaspin.

\begin{tabular}{|c|c|c|c|c|c|c|}
\hline \multirow{2}{*}{ Parameter } & \multicolumn{2}{|c|}{ Overall $(n=60)$} & \multicolumn{2}{|c|}{ Non Obese $(n=17)$} & \multicolumn{2}{|c|}{ Obese $(n=43)$} \\
\hline & $\mathbf{r}$ & $p$ & $\mathbf{r}$ & $p$ & $\mathbf{r}$ & $p$ \\
\hline \multicolumn{7}{|l|}{ IMT vs. } \\
\hline WC & $0.905^{*}$ & 0.000 & $0.784 *$ & 0.000 & $0.806^{*}$ & 0.000 \\
\hline hs-CRP & $0.321^{*}$ & 0.012 & 0.039 & 0.881 & 0.152 & 0.329 \\
\hline Progranulin & 0.033 & 0.803 & 0.178 & 0.495 & -0.065 & 0.679 \\
\hline Granulin & -0.213 & 0.103 & -0.243 & 0.347 & -0.256 & 0.098 \\
\hline Adiponectin & -0.189 & 0.147 & -0.191 & 0.463 & -0.129 & 0.409 \\
\hline Vaspin & $0.432 *$ & 0.001 & 0.193 & 0.457 & $0.339 *$ & 0.026 \\
\hline \multicolumn{7}{|l|}{ WC vs. } \\
\hline hs-CRP & $0.331 *$ & 0.010 & -0.222 & 0.392 & 0.218 & 0.160 \\
\hline Progranulin & -0.050 & 0.703 & 0.009 & 0.972 & -0.189 & 0.225 \\
\hline Granulin & -0.167 & 0.203 & -0.190 & 0.465 & -0.193 & 0.216 \\
\hline Adiponectin & -0.188 & 0.150 & -0.294 & 0.252 & -0.750 & 0.634 \\
\hline Vaspin & $0.399 *$ & 0.002 & 0.155 & 0.552 & 0.240 & 0.122 \\
\hline \multicolumn{7}{|l|}{ hs-CRP vs. } \\
\hline Progranulin & 0.093 & 0.477 & 0.251 & 0.331 & 0.048 & 0.758 \\
\hline Granulin & -0.204 & 0.119 & -0.128 & 0.624 & -0.223 & 0.150 \\
\hline Adiponectin & -0.101 & 0.445 & 0.131 & 0.616 & -0.121 & 0.439 \\
\hline Vaspin & $0.329 *$ & 0.010 & 0.312 & 0.222 & $0.305^{*}$ & 0.046 \\
\hline \multicolumn{7}{|c|}{ Adiponectin vs. } \\
\hline Progranulin & -0.131 & 0.319 & -0.481 & 0.050 & 0.029 & 0.856 \\
\hline Granulin & $0.664 *$ & 0.000 & $0.578^{*}$ & 0.015 & $0.711 *$ & 0.000 \\
\hline Vaspin & 0.029 & 0.827 & 0.322 & 0.207 & -0.063 & 0.688 \\
\hline
\end{tabular}

The independent t-test was used to evaluate the correlation between parametric parameters, except for correlation between non parametric value of Vaspin vs. other parameters, Pearson correlation test was used. 


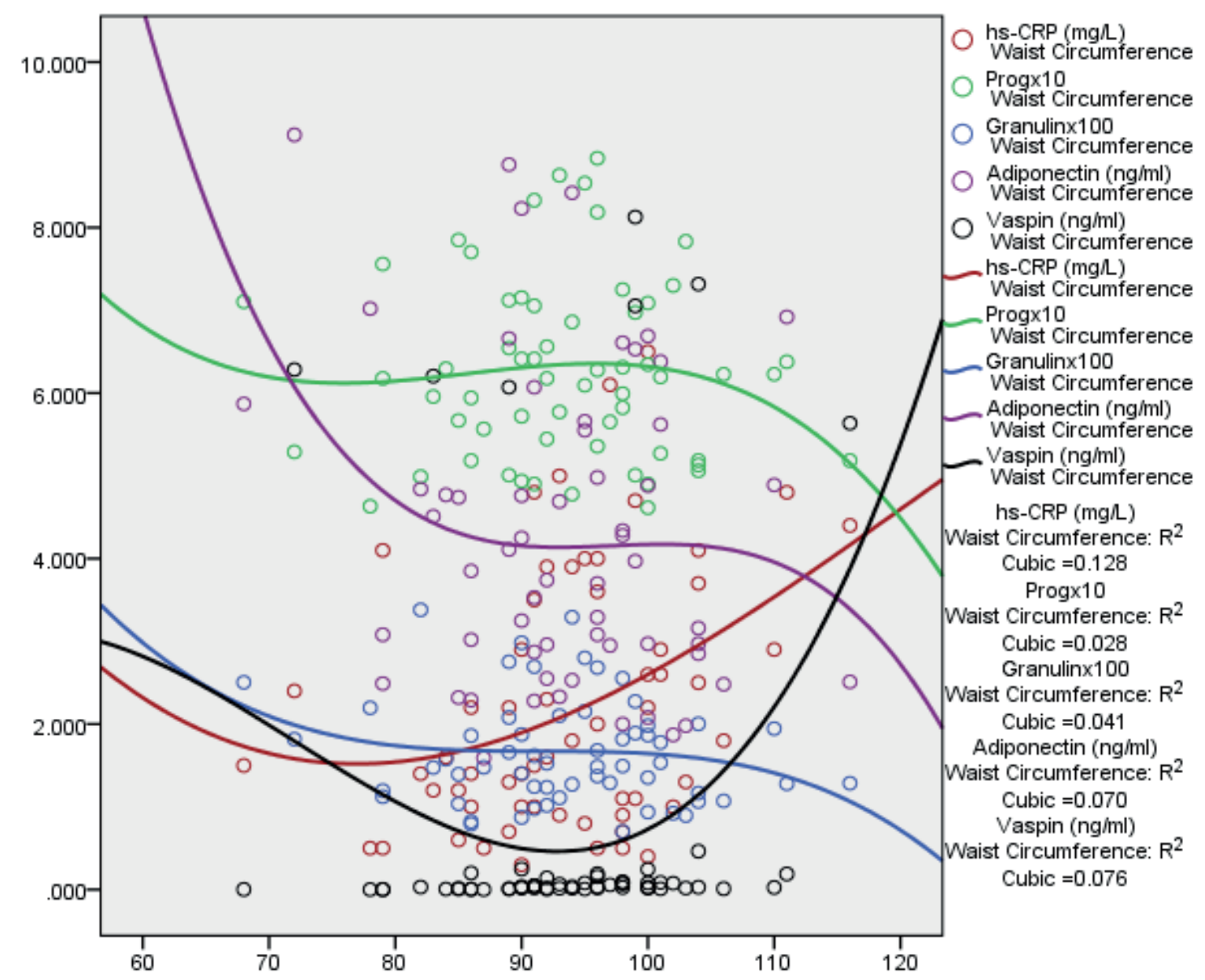

Figure 1. Scatter graph of progranulin, granulin, adiponectin, Vaspin and hs-CRP vs. WC. The graph shows similar median line patterns of progranulin, granulin and adiponectin. Similar median line patterns of vaspin and hs-CRP were also observed.

hs-CRP and Vaspin $(\mathrm{r}=0.305 ; p=0.046)$. Meanwhile, nonsignificant Pearson correlation was found between hs-CRP and progranulin $(\mathrm{r}=0.048 ; p=0.758)$, hs-CRP and granulin $(\mathrm{r}=-0.223 ; p=0.150)$, hs-CRP and adiponectin $(\mathrm{r}=-0.121$; $p=0.439$ ) (Figure 2).

\section{Discussion}

The results of this study indicate that there is a significant relationship between hs-CRP and Vaspin in men with central obesity. On the other hand there is no significant relationship between hs-CRP and progranulin, hs-CRP and granulin, hs-CRP and adiponectin.

Adipose tissue is now known as a dynamic endocrine system producing adipokines that affect the immune and metabolic systems. Increased adipocyte size in obesity is also associated with an increased inflammatory response, characterized by the changes in cytokine levels produced by adipose tissue.(10)

hs-CRP was chosen as an inflammation marker due to its good stability, precision, accuracy, availability of analyte, and good availability of a standard for calibration. hs-CRP was produced by the liver in response to inflammation, thus referred to as inflammatory markers. Several studies have linked hs-CRP with risk of heart disease, stroke and type 2-diabetes.(11)

Previous study by $\mathrm{Qu}$, et al., showed a significant association between progranulin and obesity. The study indicated that progranulin level was higher in the group with type 2-diabetes compared to the healthy group. This indicates that progranulin level is not only influenced by obesity, but also by the level of glucose tolerance in the subjects. Unfortunately, in this study we didn't perform the blood glucose test.

Increased levels of progranulin show dysfunctional interaction between macrophages and adipocytes. Progranulin acts as a chemoattractant molecule similar to MCP-1, which plays a role in enhancing macrophage infiltration into adipose tissue of patients with visceral obesity.(3) In this study, no positive significant correlation was found between progranulin and hs-CRP in all groups.

Progranulin may have a pro-inflammatory effect 

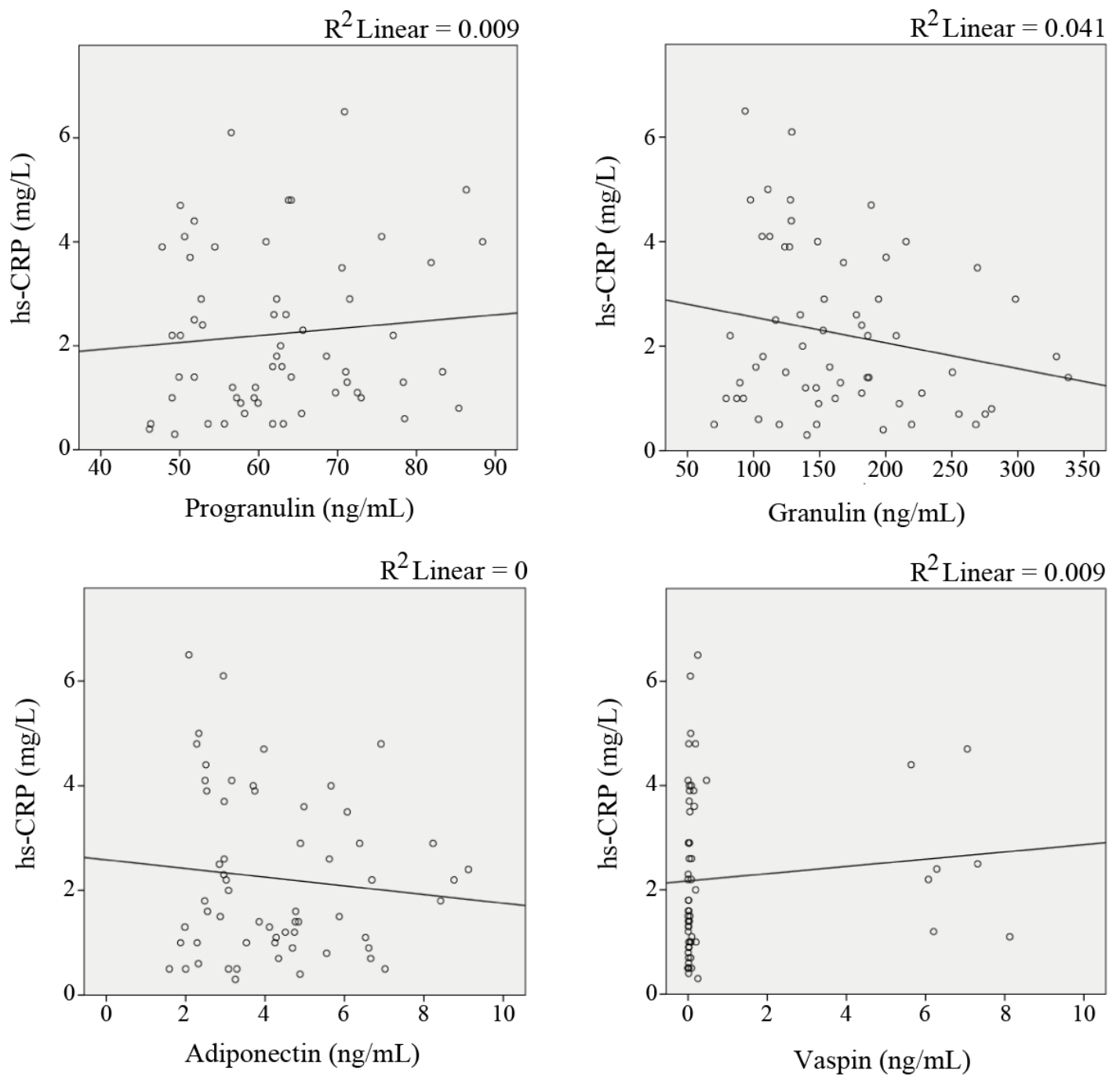

Figure 2. The corelation of progranulin, granulin, adiponectin and Vaspin vs. hs-CRP in overall subjects.

when cleaved to granulin. High density lipoprotein (HDL)/apo AI (the main component of HDL) works as an anti-inflammatory agent by preventing the cleavage of progranulin into granulin, although its mechanism remains unclear.(12) Secretory leukocyte protease inhibitor (SLPI) is secreted in response to inflammatory stimuli; suppresses TNF- $\alpha$ to activate neutrophils. SLPI binds to progranulin and protects it from elastase, an enzyme released by activated neutrophils in response to TNF- $\alpha$. When progranulin is digested by elastase, it will turn into granulin, a polypeptide that triggers epithelial cells to release neutrophil-attracting chemokine interleukin (IL)-8. Granulin can stimulate epithelial cells to secrete IL-8, which is the main cytokine that recruits neutrophils. On the other hand, progranulin may inhibit the action of TNF- $\alpha$. Progranulin exhibit antiinflammatory properties by blocking the binding of TNF to its receptors.(13-15)

In this study, progranulin showed a non-significant positive correlation with hs-CRP, whereas granulin showed a non-significant negative correlation with hs-CRP. There is a possibility that progranulin is still intact in the form in which the proteolytic processing has not happened that should form the pro-inflammatory granulin. It is suggested that SLPI or HDL might protect the progranulin from proteolysis.

In obese subjects, lower adiponectin concentration was found compared to non-obese subjects. Low level of adiponectin may cause further metabolic disease. Insulin resistance induced by TNF- $\alpha$ can be explained as being related to the inhibition mechanism of autocrine-paracrine of these adipokines.(3)

Another previous study has shown that TNF- $\alpha$ suppresses the expression of the activators involved in the gene expression of adiponectin, such as peroxisome proliferator-activated receptors (PPAR) $\gamma$. Effects of TNF- $\alpha$ on adiponectin transcription processes can be mediated by c-jun N-terminal kinase (JNK), which phosphorylates PPAR $\gamma$ and reduces its binding activity with DNA. Vice versa, adiponectin works as anti-inflammatory by suppressing the synthesis of TNF- $\alpha$ and induces anti- 
inflammatory cytokines such as IL-10 or IL-10 receptor antagonist.(16,17)

In this study the relationship between the mechanisms of progranulin, granulin and adiponectin on metaflammation process might be mediated by the role of TNF- $\alpha$, which progranulin provided anti-inflammatory effects by inhibiting TNF- $\alpha$ binding to its receptor, whereas progranulin, in the absence of protection of HDL or SLPI, would be split into pro-inflammatory granulin. The adiponectin levels were decreased in obese group, probably due to the inhibition of TNF- $\alpha$.

Study by Choi, et al., showed that Vaspin concentrations were positively correlated with BMI, WC and body fat percentage in men without MS. Results of this study showed a positive correlation between Vaspin with IMT in the overall group and obese group, which were consistent with Choi's findings. Meanwhile, compared with the WC, vaspin showed a positive correlation only in the obese group. Vaspin was correlated with the levels of fat in the body as described by a BMI being greater than the WC. Vaspin is a marker for obesity and insulin sensitivity. Increased circulating Vaspin in the subjects of the requested system of physical exercise showed an improvement of insulin resistance in the first week.(6-8)

In this study Vaspin levels decreased in non obese subjects, whereas elevated levels were found in obese subjects. This supports data of the previous study indicating that the role of Vaspin as an insulin sensitizing factor in the subjects who had experienced worsening of diabetes, a condition in which the Vaspin value would become lower.

Vaspin inhibits proteases that play a role in the degradation of proteins that are directly or indirectly lowers glucose levels and provide anti-orexigenic effect. Identification of the protease (and the target protein), which is inhibited by Vaspin, will give a better understanding of the work of Vaspin.(19)

This study showed a very interesting pattern of observed adipokines based on WC. There is a dynamics associated with the function of adipose tissue in the metaflammation process. Development of obesity depends on the coordinated interaction between adipocyte hypertrophy, adipocyte hyperplasia, and angiogenesis. Study by Marques, et al., showed that enlarged adipocytes produced growth factors that caused adipocyte proliferation and hyperplasia. The state of hypertrophy, local inflammation, and stress may affect metabolism. In this study, levels of progranulin, adiponectin and granulin showed different patterns on WC over $105 \mathrm{~cm}$, might indicate the possibility of hyperplasia, in which new adipocytes cells were capable of storing excess fat, thus affecting all three levels of the biomarker changes. (20)

Further research is needed to confirm the pro-and antiinflammatory properties of progranulin and inflammatory granulin by evaluating the levels of HDL/Apo-I. Hypertrophy and hyperplasia processes which affect the expression of adipokine are quite interesting to investigate further, so the pathophysiology of metaflammation can be explored in more depth with its relation to WC (central obesity).

\section{Conclusion}

In this study we found no significant correlation between progranulin, granulin, adiponectin and metaflammation (hs-CRP) in obese men. However, there was a significant correlation between Vaspin and metaflammation (hs-CRP) in central obese men. We therefore suggest that there is a dynamic expression of adipokines related to WC that are subjected to the role of adipocytes hypertrophy-hyperplasia pattern.

\section{References}

1. Emanuela F, Grazia M, Marco de R, Maria Paola L, Giorgio F, Marco B. Inflammation as a Link Between Obesity and Metabolic Syndrome. J Nutr Metab. 2012; 2012: 476380.

2. Okamoto Y, Kihara S, Funahashi T, Matsuzawa T, Libby P. Adiponectin: a key adipokine in metabolic syndrome. Clin Sci. 2006; 110: $267-$ 78.

3. Youn BS, Bang SI, Klöting N, Park JW, Lee N, Oh JE, et al. Serum Progranulin Concentration May Be associated With Macrophage Infiltration Into Omental Adipose Tissue. Diabetes. 2009; 58: 62736.

4. Cenik B, Sephton CF, Kutluk Cenik B, Herz J, Yu G. Progranulin: A Proteolytically Processed Protein at the Crossroads of Inflamation and Neurodegeneration. J Biol Chem. 2012; 287: 32298-306.

5. Matsubara T, Mita A, Minami K, Hosooka T, Kitazawa S, Takahashi K, et al. PGRN is a Key Adipokine Mediating High Fat Diet-Induced Insulin Resistance and Obesity through IL-6 in Adipose Tissue. Cell Metab. 2012; 15: 38-50

6. Li Q, Chen R, Moriya J, Yamakawa J, Sumino H, Kanda T, et al. A Novel Adipokine, Visceral Adipose Tissue-Derived Serine Protease Inhibitor (Vaspin), and Obesity. J Int Med Res. 2008; 36: 625-9.

7. Auguet T, Quintero Y, Riesco D, Morancho B, Terra X, Crescenti A, et al. New Adipokines Vaspin and Omentin. Circulating Levels and Gene Expression in Adipose Tissue from Morbidly Obese Women. BMC Med Genet. 2011; 12: 60.

8. Koiou E, Kalaitzakis E, Tziomalos K, Mavridis S, Dinas K, Tantanasis $\mathrm{T}$, et al. Vaspin: a novel adipokine, member of the family of serine protease inhibitors. Aristotle Univ Med J. 2011; 38: 7-18.

9. Rocha VZ, Folco EJ. Inflammatory Concepts of Obesity. Int J Inflam. 2011; $2011: 1-14$.

10. Papizan, James B. Phosporylation of Fetuin-A. Physiological inhibitor 
of Insulin Action, Regulated by Insulin and Leptin. Alabama: Prostgraduate Program Universitas Auburn University. 2007.

11. Pearson TA, Mensah GA, Alexander RW. Markers of Inflammation and Cardiovascular Disease: Application to Clinical and Public Health Practice a Statement for Healthcare Professionals from the Centers for Disease Control and Prevention and the American Heart Association. Circulation. 2003; 107: 499-511.

12. Okura H, Yamashita S, Ohama T, Saga A, Yamamoto-Kakuta A, Hamada Y, et al. HDL/Apolipoprotein A-I Binds to Macrophage-Derived Progranulin and Suppresses its Conversion into Proinflammatory Granulins. J Atheroscler Thromb. 2010; 17: 568-77.

13. Ong $\mathrm{CH}$, Bateman A. Progranulin (Granulin-epithelin precursor, PC-cell derived growth factor, Acroganin) in proliferation and tumorigenesis. Histol Histopathol. 2003; 18: 1275-88.

14. Tang W, Lu Y, Tian QY, Zhang Y, Guo FJ, Liu GY, et al. The Growth Factor Progranulin Binds to TNF Receptors and Is Therapeutic Against Inflammatory Arthritis in Mice. Science. 2011; 332: 47884.

15. Nathan C, Ding A. Nonresolving Inflammation, Cell. 2010; 140: 87182.

16. Tilg H, Hotamisligil GS. Nonalcoholic fatty liver disease: Cytokineadipokine interplay and regulation of insulin resistance. Gastroenterology. 2006; 131: 934-45.

17. Shehzad A, Iqbal W, Shehzad O, Lee YS. Adiponectin: Regulation of its production and its role in human diseases. Hormones. 2012; 11: 8-20.

18. Cho SH, Kwak SH, Lee Y, Moon MK, Lim S, Park YJ, et al. Plasma Vaspin Concentrations are Elevated in Metabolic Syndrome in Men and are Correlated with Coronary Atheroscerosis in Women. Clin Endocrinol. 2011; 75: 628-35.

19. Blüher M. Vaspin in obesity and diabetes: pathophysiological and clinical significance. Endocrine. 2012; 41: 176-82.

20. Marques BG, Hausman DB, Martin RJ. Association of fat cell size and paracrine growth factors in development of obesity. Am J Physiol. 1998; 275: 1898-908. 